\title{
The Influence of Metal-complexing Agents on Gitric Acid Production by Aspergillus niger
}

\author{
By A. QADEER CHOUDHARY AND S. J. PIRT \\ Microbiology Department, Queen Elizabeth College, \\ University of London, London, W. 8
}

(Received 17 September 1965)

\begin{abstract}
SUMMARY
Addition of any of the chelating agents ethylenediaminetetra-acetic acid, diamino-cyclohexane- $N, N$-tetra-acetic acid or diethylenetriaminepenta-acetic acid at about $1.0 \mathrm{mM}$ to a sugar $+\mathrm{NH}_{4} \mathrm{NO}_{3}+$ salts medium stimulated citric acid production by Aspergillus niger. The greatest stimulation (about tenfold) was obtained with EDTA (1.0 mM). In contrast, potassium ferrocyanide at $84 \mu \mathrm{M}$ stimulated citric acid production about 20-fold. Ferrocyanide was effective only when present at the beginning of the mycelial growth period, whereas the chelating agents were effective at any time during the growth period. Stimulation of citric acid production by ferrocyanide could be repressed by transferring the mycelium to fresh medium without ferrocyanide, or by removal of the ferrocyanide precipitate in the medium. Analyses of the iron, copper and zinc contents of the mould mycelium are given. Ferrocyanide did not affect the copper and zinc contents of the mycelium: EDTA did not affect the iron, copper and zinc contents of the mycelium.
\end{abstract}

\section{INTRODUCTION}

Aspergillus niger produces large amounts of citric acid from sugars under certain conditions and this organism is used for the industrial production of citric acid. Crucial conditions in the fermentation are: the strain of the organism, the metal ion nutrition, and the physical environment of the mould. Perlman \& Sih (1960) reviewed work on this process. The cultivation process is empirical and its mechanism not understood. One of the unexplained effects is the increase in citric acid yield caused by addition of a small amount of ferrocyanide to the medium. We chose the citric acid fermentation for a study of the effects of metal-chelating agents (as metal buffers) in culture media and have observed that certain chelating agents, like ferrocyanide, increase the yield of citric acid. The present paper reports these effects and discusses their.significance. In a previous paper (Choudhary \& Pirt, $1965 a$ ) the effects of metal buffers on the growth of Aspergillus niger were discussed.

\section{METHODS}

General. Details of media and cultural methods were described previously (Choudhary \& Pirt, 1965a). The general procedure for the production of citric acid with Aspergillus niger was as follows: $25 \mathrm{ml}$. of medium $\mathrm{M2}$ (carbon source, glucose at $150 \mathrm{~g}$./1.) was placed in a $250 \mathrm{ml}$. conical flask, inoculated with conidia and incubated at $25^{\circ}$ for 7 days on a rotary shaker. Potassium ferrocyanide, when 
required, was added $24 \mathrm{hr}$ after inoculation unless otherwise stated; other chelating agents were added before inoculation unless otherwise stated. In addition to the two strains of $A$. niger, Wis 72-4 and IMI-31821 (i), previously described (Choudhary \& Pirt, 1965 a) we also used the strain N-548 of Noguchi \& Johnson (1961), supplied by Professor M. J. Johnson (Biochemistry Dept., University of Wisconsin). Media were sterilized by autoclaving; potassium ferrocyanide solution was sterilized by membrane filtration. The medium was initially at $\mathrm{pH} \mathrm{3.5}$ and finally at about pH 2.

Wet ashing for trace metal analysis. Trace metals in mycelium and culture filtrate were determined after wet ashing. Cultures were filtered through filter paper in Buchner funnels. After thorough washing with de-ionized water the mycelium was transferred to a watch-glass using a glass rod, and dried overnight at $105^{\circ}$. Mycelium $\left(0 \cdot 8-1 \cdot 0\right.$ g.) was placed in a $300 \mathrm{ml}$. Kjeldahl flask, $5 \mathrm{ml} . \mathrm{HNO}_{3}$ and $1 \mathrm{ml}^{-\mathrm{H}_{2} \mathrm{SO}_{4}}$ added and the flask heated gently so that the solution just started to boil. A further addition of $5 \mathrm{ml}$. $\mathrm{HNO}_{3}$ was made as the solution began to char and when the oxidation had practically ceased, $1 \mathrm{ml}$. perchloric acid was added and the flask heated slightly more vigorously until white fumes began to form. Heating was continued until the solution was colourless. Samples of culture medium (10-15 ml.) were transferred to $300 \mathrm{ml}$. Kjeldahl flasks and evaporated to dryness. Wet ashing was then done by the procedure described above.

All the vessels and apparatus brought in contact with trace metal solutions for analysis were cleaned by standing for 2-3 hr in a boiling sulphuric acid + sodium nitrate mixture. The glass apparatus was then washed three or four times with glass-distilled water.

Estimations of $\mathrm{Fe}^{3+}, \mathrm{Zn}^{2+}, \mathrm{Cu} \mathrm{u}^{2+}$ and $\mathrm{M} n^{2+}$. Iron was determined by means of the $\alpha, \alpha^{\prime}$-dipyridyl method of Jackson (1938). The digest was diluted with water to about $10 \mathrm{ml}$, and neutralized by dropwise addition of approximately $8 \mathrm{ml}$. concn. ammonium hydroxide (bromophenol blue as internal indicator). The solution was then diluted to $100 \mathrm{ml}$. and a sample taken for the analysis.

To determine copper the Zincon method of McCall, Davis \& Stearns (1958) was first tried but the reported colour was not developed. Instead, the diethyldithiocarbonate method of Eden \& Green (1940) as modified by Arman (1957) was used. A sample of the neutralized digest was used for the analysis.

Zinc was determined by the dithizone 'mixed colour' method described by Sandell (1944). A sample of the neutralized digest was used for the analysis.

Manganese was estimated by the permanganate method of Sandell (1944), the un-neutralized digest of the mycelium or culture filtrate being used for analysis.

Other analyses. The $\mathrm{CO}_{2}$ and $\mathrm{O}_{2}$ in the effluent gas from the continuous-flow culture were analysed by the methods described by Pirt \& Callow (1958). Samples of the culture filtrate were used for assaying citric acid and reducing sugar content. Citric acid was estimated colorimetrically by the method of Marier \& Boulet (1958). The sample range was $20-200 \mu \mathrm{g}$. citric acid $/ \mathrm{ml}$.; the estimation was unaffected by glucose up to $2.0 \mathrm{mg} . / \mathrm{ml}$.

Reducing sugars (glucose and hydrolysed sucrose) were estimated by a modification of the ferricyanide method of Fujita \& Iwatake (1931). The estimation was unaffected by the citric acid present in the sample. Sucrose was hydrolysed by the method of Pirt \& Callow (1958). 
Yield of citric acid (\%) is expressed as: (g. citric acid produced/g. sugar utilized) $\times 100$.

Chelating agents were obtained from Hopkin and Williams Ltd., Chadwell Heath Essex, England.

\section{RESULTS}

\section{Action of chelating agents on citric acid production}

Effect of concentration of chelating agent. The effect of chelating agents on citric acid production by Aspergillus niger was examined by growing the mould in medium M2 in shake-flasks with the addition of one of the following chelating agents: ethylenediaminetetra-acetic acid (EDTA), 1,2-diaminocyclohexane- $N, N$-tetraacetic acid (CTDA), diethylenetriaminepenta-acetic acid (DTPA), nitrilotriacetic

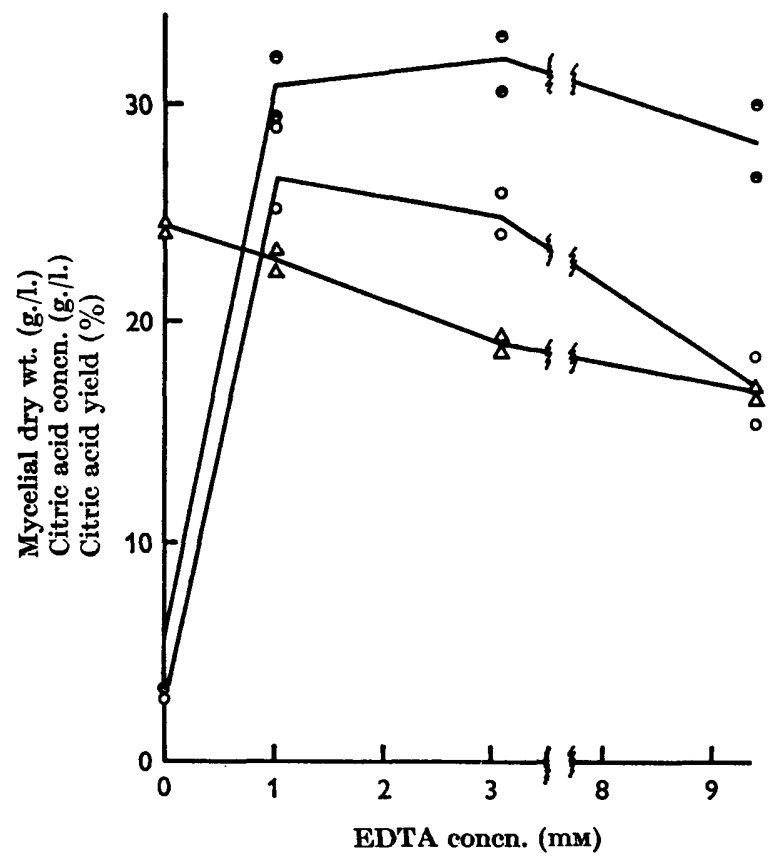

Fig. 1

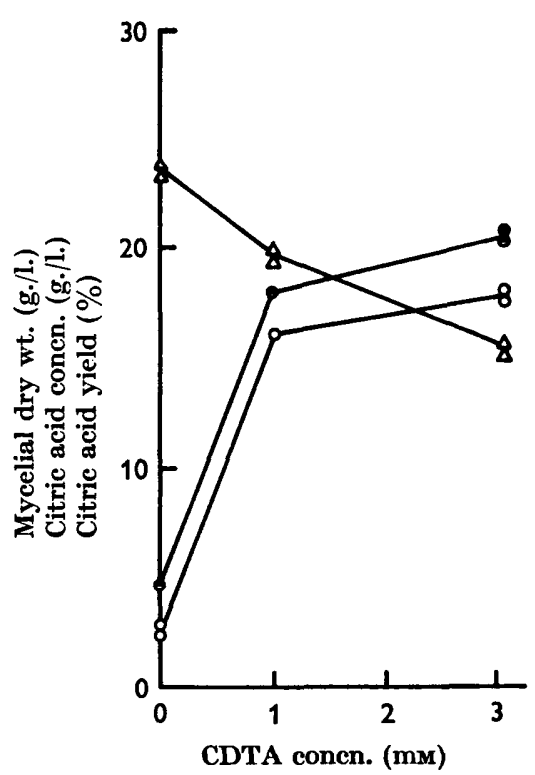

Fig. 2

Fig. 1. The effect of EDTA (0-9.4 mM; added at the time of inoculation) on citric acid production from glucose after 7 days by strain 72-4. Citric acid concn. 0 ; $\%$ citric acid yield, $\Theta$; mycelial dry-wt. concn., $\triangle$.

Fig. 2. The effect of CDTA (0-3.13 mM; added at the time of inoculation) on citric acid production by strain r2-4. Citric acid concn., $O$; \% citric acid yield, $\Theta$; mycelial dry-wt. conen., $\triangle$.

acid (NTA) and dihydroxyethylglycine (DHEG). The effects of EDTA, CDTA and DTPA at different concentrations are shown in Figs. 1, 2 and 3. Each of these chelating agents stimulated citric acid production, the maximum stimulation being reached with the chelating agent in the range 1-3 mM. Similar results were obtained with strain N-548. The results with strain IMI-31821 (i) were qualitatively similar but the concentration and percentage yield of citric acid were only about one-third 
of those obtained with the other two strains. The agents NTA and DHEG at concentrations up to $\mathbf{9 \cdot 4} \mathrm{mm}$ had no effect on citric acid production.

Effect of time of addition of chelating agent. The effect of adding EDTA or DTPA to shake-flask cultures at different times after inoculation with conidia was investigated. The effect of time of addition of 1.04 mM-EDTA with strain 72-4 is illustrated in Fig. 4. The results show that the chelating agents stimulated the production of citric acid when added at any time up to $72 \mathrm{hr}$ after inoculation but maximum stimulation occurred with the addition between 0 and $24 \mathrm{hr}$. In a control medium (without added chelating agent) strain $72-4$ produced $3.0 \pm 0.5 \mathrm{~g} . / 1$. of citric acid after 7 days with a $3 \%$ yield and the mycelial dry wt. was $22.0 \pm 1.5 \mathrm{~g} . / 1$.

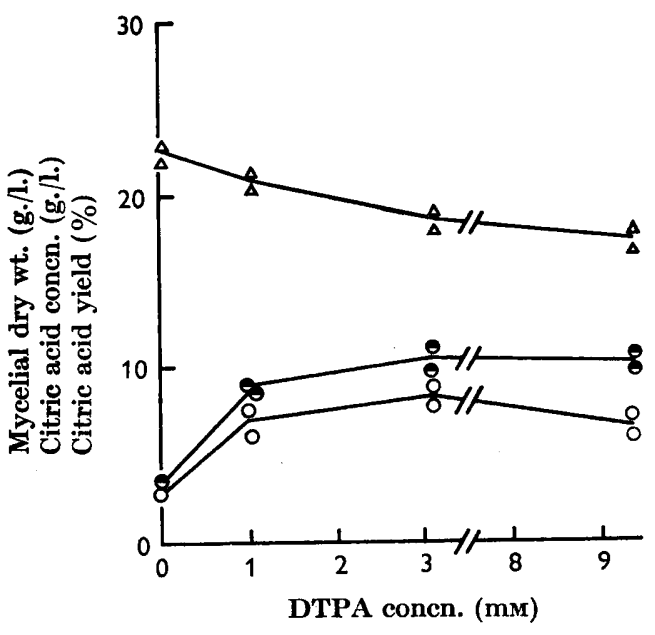

Fig. 3

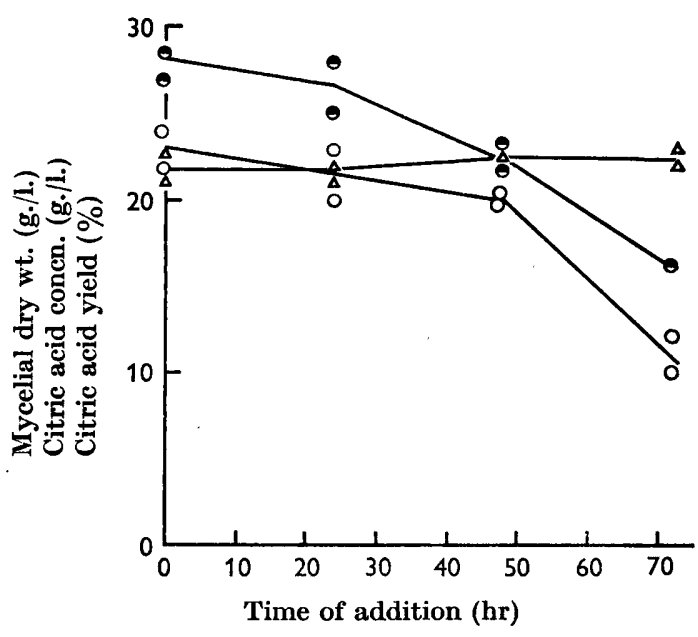

Fig. 4

Fig. 3. The effect of DTPA (0-9.4 mM; added at the time of inoculation) on citric acid production by strain 72-4. Citric acid concn., $O$; $\%$ citric acid yield, $\theta$; mycelial dry-wt. concn., $\triangle$.

Fig. 4. The effect of EDTA (1.04 mM), added at various times after inoculation, on citric acid production by strain 72-4. Citric acid concn., $\bigcirc$; $\%$ citric acid yield, $\ominus$; mycelial dry-wt. conen., $\triangle$.

Effect of increasing both ferric ion and EDTA concentrations. An experiment was made to see whether the stimulation of citric acid production was controlled by the $\mathrm{Fe}^{3+}$ :EDTA ratio. In a preliminary experiment it was found that maximum citric acid production occurred when the $\mathrm{Fe}^{3+}$ : EDTA molar ratio was about $1: 30$. In a second experiment the $\mathrm{Fe}^{3+}$ content of the medium was increased and the EDTA concn. was also increased to keep the $\mathrm{Fe}^{3+}$ :EDTA ratio constant at either of 3 values; $1: 12.5,1: 25$ or $1: 37 \cdot 5$. The results are shown in Table 1 . The iron present as a contaminant in the medium constituents was determined colorimetrically and allowed for in calculating the $\mathrm{Fe}^{3+}$ :EDTA ratio. The results show that the mycelial dry wt. was unaffected. At each $\mathrm{Fe}^{3+}$ : EDTA ratio, an increase in the $\mathrm{Fe}^{3+}$ concn. decreased the citric acid production. Therefore the $\mathrm{Fe}^{3+}$ : EDTA ratio alone did not control the citric acid production; some other factor must also have been involved. However, with the lowest $\mathrm{Fe}^{3+}$ :EDTA ratio there was some suppression of the inhibition caused by increased $\mathrm{Fe}^{3+}$ concn. 
Table 1. Effect of varying $F e^{3+}$ concentration and $F e^{3+}: E D T A$ ratio on citric acid production by strain 72-4

\begin{tabular}{|c|c|c|c|c|c|c|c|c|c|}
\hline \multirow[b]{3}{*}{$\begin{array}{c}\mathrm{Fe}^{3+} \\
\text { concn. } \\
(\mu \mathrm{M})^{*}\end{array}$} & \multicolumn{9}{|c|}{$\mathrm{Fe}^{\mathbf{3}+}:$ EDTA molar ratio } \\
\hline & \multicolumn{3}{|c|}{$1: 12 \cdot 5$} & \multicolumn{3}{|c|}{$1: 25$} & \multicolumn{3}{|c|}{$1: 37 \cdot 5$} \\
\hline & $\begin{array}{l}\text { Mycelial } \\
\text { dry wt. } \\
\text { (g./l.) }\end{array}$ & $\begin{array}{c}\text { Citric } \\
\text { acid } \\
\text { (g./l.) }\end{array}$ & $\begin{array}{c}\% \text { citric } \\
\text { acid } \\
\text { yield }\end{array}$ & $\begin{array}{l}\text { Mycelial } \\
\text { dry wt. } \\
\text { (g./l.) }\end{array}$ & $\begin{array}{l}\text { Citric } \\
\text { acid } \\
\text { (g./l.) }\end{array}$ & $\begin{array}{c}\% \text { citric } \\
\text { acid } \\
\text { yield }\end{array}$ & $\begin{array}{c}\text { Mycelial } \\
\text { dry wt. } \\
\text { (g./l.) }\end{array}$ & $\begin{array}{r}\text { Citric } \\
\text { acid } \\
\text { (g./l.) }\end{array}$ & $\begin{array}{c}\% \text { citric } \\
\text { acid } \\
\text { yield }\end{array}$ \\
\hline 42 & $17 \cdot 2$ & $15 \cdot 2$ & $15 \cdot 2$ & $17 \cdot 5$ & $25 \cdot 0$ & 26.0 & $16 \cdot 5$ & $23 \cdot 0$ & $23 \cdot 0$ \\
\hline 96 & $18 \cdot 0$ & $5 \cdot 5$ & $\mathbf{5 \cdot 5}$ & $15 \cdot 0$ & $7 \cdot 0$ & $8 \cdot 1$ & $18 \cdot 3$ & $9 \cdot 0$ & $11 \cdot 3$ \\
\hline 266 & $17 \cdot 0$ & $1 \cdot 1$ & $2 \cdot 3$ & $17 \cdot 0$ & 1.0 & $1 \cdot 1$ & $18 \cdot 0$ & 4.5 & $5 \cdot 8$ \\
\hline 518 & $16 \cdot 5$ & 3.5 & 4.0 & $18 \cdot 3$ & $2 \cdot 5$ & $2 \cdot 5$ & $18 \cdot 6$ & 6.5 & 11.5 \\
\hline
\end{tabular}

* Added iron + iron contamination $(14 \mu \mathrm{M})$ in medium constituents.

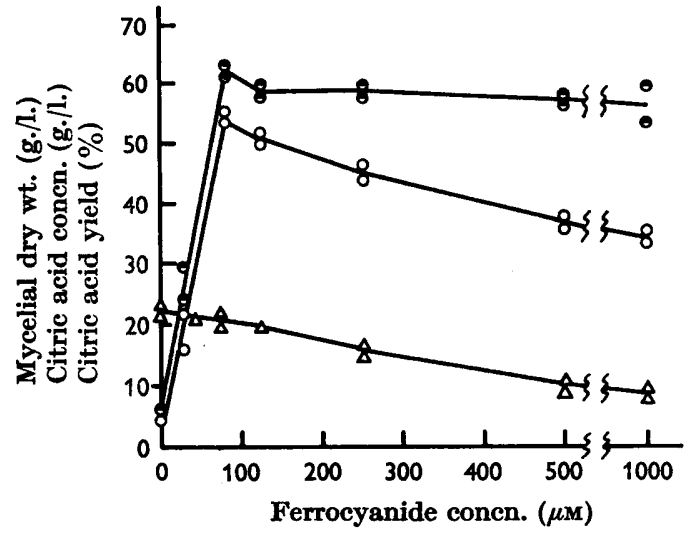

Fig. 5

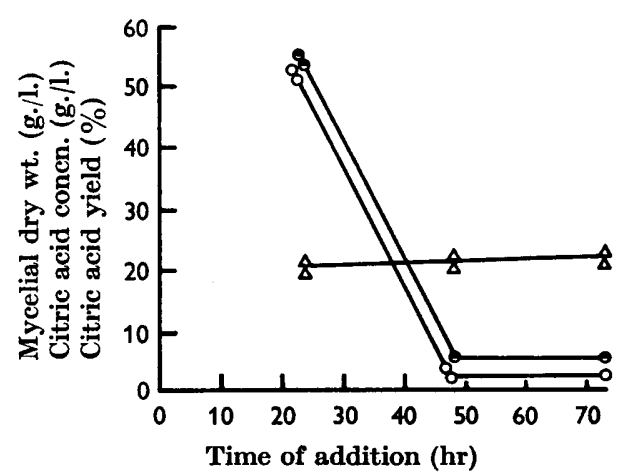

Fig. 6

Fig. 5. The effect of ferrocyanide concn. on the synthesis of citric acid from glucose by strain 72-4. The ferrocyanide was added $24 \mathrm{hr}$ after inoculation with conidia and the culture duration was 7 days. Citric acid concn., $O$; $\%$ citric acid yield, $\theta$; mycelial dry-wt. concn., $\triangle$.

Fig. 6. The effect of time of addition of ferrocyanide (84 $\mu \mathrm{M})$ on the production of citric acid from glucose by strain 72-4. Citric acid concn., $O$; $\%$ citric acid yield, $\Theta$; mycelial dry-wt. conen., $\triangle$.

\section{Action of ferrocyanide on citric acid synthesis}

Effect of ferrocyanide concentration. Potassium ferrocyanide was added to the media in shake-flask experiments to characterize the ferrocyanide action and to compare it with that of the chelating agents. The influence of ferrocyanide concn. is shown in Fig. 5. The maximum concentration and percentage yield of citric acid were reached with $84 \mu \mathrm{M}$ ferrocyanide. The decrease in citric acid production at higher ferrocyanide concentration may be attributed to the reduced amount of mycelium. Strain N-548 showed a similar response to ferrocyanide but produced less mycelium and consequently gave a lower citric acid yield (44 g./l.). When sucrose was used as the carbon source, even larger amounts of citric acid ( $80 \mathrm{~g} . / \mathrm{l}$.$) were produced by$ strain 72-4 in 7 days with a $65 \%$ yield. Apparently sucrose was converted more quickly than glucose into citric acid.

Effect of time of addition of ferrocyanide. The effect of adding the optimum amount 
of ferrocyanide $(84 \mu \mathrm{M})$ to the culture at different times is shown in Fig. 6. At $84 \mu \mathrm{M}$ and $\mathrm{pH} \mathrm{3.5}$, ferrocyanide inhibited the germination of conidia and hence could not be added initially. The most notable point is that the ferrocyanide unlike the chelating agents was without effect when added at $48 \mathrm{hr}$ or later. Moreover, the mould grew in the small pellet form (Choudhary \& Pirt, 1965 a) only when the ferrocyanide was added at $24 \mathrm{hr}$, i.e. at the beginning of the mycelial growth period. It may be postulated that growth of the mould in the presence of ferrocyanide

Table 2. Citric acid production by strain 72-4 in nitrogen-free medium $M 2$ with and without ferrocyanide

\begin{tabular}{|c|c|c|c|c|c|c|c|}
\hline \multirow{2}{*}{$\begin{array}{l}\text { Nitrogen } \\
\text { source }\end{array}$} & \multirow{2}{*}{$\begin{array}{c}\text { Ferro- } \\
\text { cyanide } \\
\text { concn. } \\
(\mu \mathrm{M})\end{array}$} & \multirow[b]{2}{*}{ Inoculum } & \multirow{2}{*}{$\begin{array}{c}\text { Time of } \\
\text { sample } \\
\text { (days) }\end{array}$} & \multirow{2}{*}{$\begin{array}{c}\text { Mean } \\
\text { mycelial } \\
\text { dry wt. } \\
\text { (g./l.) }\end{array}$} & \multicolumn{2}{|c|}{$\begin{array}{l}\text { Mean citric } \\
\text { acid amount }\end{array}$} & \multirow[b]{2}{*}{ Replicates } \\
\hline & & & & & (g./l.) & $\%$ yield & \\
\hline Absent & $\mathbf{0}$ & 48-hr mycelium & $\begin{array}{l}3 \\
5 \\
7\end{array}$ & $\begin{array}{r}9 \cdot 5 \\
12 \cdot 5 \\
10 \cdot 0\end{array}$ & $\begin{array}{l}\mathbf{3} \cdot \mathbf{3} \\
\mathbf{3} \cdot 8 \\
4 \cdot 0\end{array}$ & $\left.\begin{array}{r}7 \cdot 0 \\
11 \cdot 5 \\
12 \cdot 0\end{array}\right\}$ & 2 \\
\hline Absent & 84 & 48-hr mycelium & $\begin{array}{l}3 \\
5 \\
7\end{array}$ & $\begin{array}{l}9 \cdot 5 \\
9 \cdot 2 \\
9 \cdot 6\end{array}$ & $\begin{array}{l}5 \cdot 0 \\
8 \cdot 0 \\
8 \cdot 5\end{array}$ & $\left.\begin{array}{l}16 \cdot 0 \\
21 \cdot 0 \\
20 \cdot 0\end{array}\right\}$ & $\mathbf{3}$ \\
\hline Absent & $\mathbf{0}$ & 72-hr mycelium & $\begin{array}{l}2 \\
4 \\
6\end{array}$ & $\begin{array}{r}9 \cdot 5 \\
13 \cdot 5 \\
13 \cdot 6\end{array}$ & $\begin{array}{l}5 \cdot 0 \\
7 \cdot 5 \\
8 \cdot 0\end{array}$ & $\left.\begin{array}{c}16 \cdot 0 \\
15 \cdot 0 \\
16 \cdot 0\end{array}\right\}$ & $\mathbf{3}$ \\
\hline Absent & 84 & 72-hr mycelium & $\begin{array}{l}2 \\
4 \\
6\end{array}$ & $\begin{array}{l}10 \cdot 0 \\
12 \cdot 0 \\
14 \cdot 0\end{array}$ & $\begin{array}{l}10 \cdot 0 \\
14 \cdot 0 \\
15 \cdot 0\end{array}$ & $\left.\begin{array}{l}30 \cdot 0 \\
30 \cdot 0 \\
29 \cdot 0\end{array}\right\}$ & $\mathbf{3}$ \\
\hline Present & $\mathbf{0}$ & Conidia & $\begin{array}{l}5 \\
7\end{array}$ & $\begin{array}{l}17 \cdot 0 \\
20 \cdot 8\end{array}$ & $\begin{array}{l}2 \cdot 5 \\
3 \cdot 0\end{array}$ & $\left.\begin{array}{l}4 \cdot 3 \\
\mathbf{3} \cdot 3\end{array}\right\}$ & 2 \\
\hline Present & 84 & Conidia & $\begin{array}{l}5 \\
7\end{array}$ & $\overline{20 \cdot 0}$ & $\begin{array}{l}27 \cdot 5 \\
60 \cdot 0\end{array}$ & $\left.\begin{array}{l}32 \cdot 0 \\
50 \cdot 0\end{array}\right\}$ & 2 \\
\hline
\end{tabular}

induces a mechanism for acid accumulation which is unaffected by subsequent removal of ferrocyanide. This hypothesis was tested in experiments with washed mycelium grown in the presence of ferrocyanide. Mould mycelium was grown in the presence of $84 \mu \mathrm{M}$-ferrocyanide for 48 and $72 \mathrm{hr}$; the mycelium was then filtered off in a chamber of sterile air (Harris-Smith, Pirt \& Firman, 1963) and thoroughly washed with sterile distilled water. The washed mycelium was then aseptically transferred to $30 \mathrm{ml}$. of medium $\mathrm{M2}$, with or without ferrocyanide $(84 \mu \mathrm{M})$, and without $\mathrm{NH}_{4} \mathrm{NO}_{3}$ to prevent further growth. The flasks were then incubated on the shaker. As controls, unfiltered cultures were run in parallel, with and without ferrocyanide $(84 \mu \mathrm{M})$. At intervals $4 \mathrm{ml}$. samples of culture were taken by pipette and analysed for citric acid, glucose and mycelial dry wt. The results (Table 2) show that for maximum citric acid production the nitrogen-free replacement medium needed to have ferrocyanide added. The omission of ferrocyanide from the replacement medium decreased the production of citric acid by about $50 \%$. Some of the citric acid producing ability induced by the preliminary growth in ferrocyanide was retained. This result is interpreted to mean that the medium untreated with ferrocyanide contains some material which can reverse the change which ferrocyanide induces in the mycelium.

Influence of ferrocyanide precipitate on citric acid production. One hypothesis to 
account for the role of ferrocyanide is that it makes the medium suitable for citric acid production by precipitating iron or other cations, thus causing the mycelium to be deficient in iron. It may therefore be expected that if ferrocyanide is added to the medium and the precipitate removed, this treated medium should give maximum citric acid production when inoculated. This hypothesis was tested in the following way. Conidia were germinated in medium $\mathrm{M2}$ and the resultant mycelium after incubation for $26 \mathrm{hr}$ was thoroughly washed with de-ionized water in sintered-glass crucibles placed in the cabinet with a sterile atmosphere. Part of the washed mycelium was used to inoculate medium $\mathrm{M} 2$ to which $84, \mu \mathrm{M}$-ferrocyanide had been added $24 \mathrm{hr}$ previously. Another part of the washed mycelium was used to inoculate medium $\mathrm{M2}$ after removing the ferrocyanide precipitate by membrane filtration $24 \mathrm{hr}$ after the addition of ferrocyanide at $84 \mu \mathrm{M}$. The mould in the replacement

Table 3. Effect of removal of ferrocyanide precipitate from medium $M 2$ on the production of citric acid by strain 72-4

\begin{tabular}{|c|c|c|c|c|c|c|c|}
\hline \multirow{2}{*}{$\begin{array}{l}\text { Ferro- } \\
\text { cyanide } \\
\text { concn. } \\
(\mu \mathrm{M})\end{array}$} & \multirow[b]{2}{*}{ Inoculum } & \multirow[b]{2}{*}{$\begin{array}{l}\text { Medium } \\
\text { treatment }\end{array}$} & \multirow[b]{2}{*}{$\begin{array}{l}\text { Time of } \\
\text { sample } \\
\text { (days) }\end{array}$} & \multirow[b]{2}{*}{$\begin{array}{c}\text { Mean } \\
\text { dry wt. } \\
\text { (g./l.) }\end{array}$} & \multicolumn{2}{|c|}{ Citric acid } & \multirow[b]{2}{*}{$\begin{array}{r}\text { Repli- } \\
\text { cates }\end{array}$} \\
\hline & & & & & $\begin{array}{c}\text { Mean } \\
\text { conen. } \\
(\text { g./l.) }\end{array}$ & $\begin{array}{c}\% \\
\text { yield }\end{array}$ & \\
\hline 0 & Conidia & None & 7 & $22 \cdot 5$ & $3 \cdot 0$ & $\mathbf{3} \cdot \mathbf{0}$ & 2 \\
\hline 84 & Conidia & None & 7 & 17.5 & $58 \cdot 0$ & $50 \cdot 0$ & 2 \\
\hline o & $\begin{array}{l}\text { Washed myce- } \\
\text { lium } 26 \mathrm{hr}\end{array}$ & None & 6 & $23 \cdot 0$ & $2 \cdot 0$ & $\mathbf{2 \cdot 0}$ & 2 \\
\hline 84 & $\begin{array}{l}\text { Washed myce- } \\
\text { lium } 26 \mathrm{hr}\end{array}$ & $\begin{array}{l}\text { Ferrocyanide } \\
\text { added } 24 \mathrm{hr} \\
\text { before inocu- } \\
\text { lation }\end{array}$ & 6 & $20 \cdot 0$ & $23 \cdot 0$ & $22 \cdot 0$ & 4 \\
\hline 84 & $\begin{array}{l}\text { Washed myce- } \\
\text { lium } 26 \mathrm{hr}\end{array}$ & $\begin{array}{l}\text { Ferrocyanide } \\
\text { added, ppt. } \\
\text { removed after } \\
24 \text { hr and } \\
\text { then inocu- } \\
\text { lated }\end{array}$ & 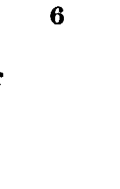 & $20 \cdot 0$ & $\mathbf{2 \cdot 2}$ & $2 \cdot 0$ & 4 \\
\hline
\end{tabular}

medium with ferrocyanide precipitate developed in the form of large filamentous but separate pellets. In the same medium with ferrocyanide precipitate removed the mould developed as a viscous conglomerate of large filamentous pellets. The effects on citric acid production and mycelial dry weight are shown in Table 3. The removal of the ferrocyanide precipitate from the replacement medium prevented stimulation of citric acid production. Some decrease of stimulation of citric acid formation resulted just from the transfer of the mould to the replacement medium. The important point established is that the presence of the ferrocyanide precipitate in the medium was essential for the stimulation of citric acid production. The function of the ferrocyanide precipitate may be to maintain a low concentration of $\mathrm{Fe}^{3+}$ or other metal ions in the medium.

Effects of metal-complexing agents on the trace-metal uptake by the mould

Experiments were made to determine whether or not there was a relation between the uptake of trace metals by the mycelium and citric acid production. Iron, copper and zinc in the mycelium and medium were estimated. The concentration of man- 
ganese in the mycelium (1-2 g.) and in the filtrate (10-15 ml.) was below the amount ( $1 \mu \mathrm{g}$.$) which could be estimated. Iron was not estimated in the cultures$ containing ferrocyanide.

Trace-metal analyses were done on mycelium and culture filtrates from cultures grown with and without EDTA, and with and without ferrocyanide. Citric acid production and the mycelial dry weights were determined, to correlate them with the trace-metal analyses. The results are given in Table 4. The excess of trace metal over that added represents the amount of metal contamination in the medium. The results show that EDTA did not significantly affect the uptake of $\mathrm{Fe}^{3+}, \mathrm{Cu}^{2+}$ and $\mathrm{Zn}^{2+}$ by the mycelium. Also the ferrocyanide did not affect the $\mathrm{Cu}^{2+}$ and $\mathrm{Zn}^{2+}$ uptakes by the mycelium. Thus no relation was found between the trace-metal uptake by the mycelium and the citric acid production.

Table 4. Trace-metal analyses of mycelium and medium from 7-day cultures of strain 72-4 in medium M2 with and without metal-complexing agents*

\begin{tabular}{|c|c|c|c|c|c|c|c|c|c|c|}
\hline \multirow{4}{*}{$\begin{array}{c}\text { Chelating } \\
\text { agent } \\
\text { (concn.) }\end{array}$} & \multirow{4}{*}{$\begin{array}{c}\text { Mycelial } \\
\text { dry wt. } \\
\text { (g./l.) }\end{array}$} & & & \multirow{4}{*}{$\begin{array}{l}\text { Repli- } \\
\text { cates }\end{array}$} & \multicolumn{6}{|c|}{ Trace metals present $\dagger$} \\
\hline & & \multicolumn{2}{|c|}{ Citric acid } & & \multirow{2}{*}{\multicolumn{3}{|c|}{$\begin{array}{c}\text { Mycelium } \\
\text { ( } \mu \mathrm{g} \cdot / \mathrm{g} . \text { dry wt.) }\end{array}$}} & \multirow{2}{*}{\multicolumn{3}{|c|}{$\begin{array}{l}\text { Culture filtrate } \\
(\mu \mathrm{g} . / 1 .)\end{array}$}} \\
\hline & & \multirow{2}{*}{$\begin{array}{c}\text { Concn. } \\
\text { (g./1.) }\end{array}$} & \multirow{2}{*}{$\begin{array}{c}\% \\
\text { yield }\end{array}$} & & & & & & & \\
\hline & & & & & $\mathrm{Fe}^{3+}$ & $\mathrm{Cu}^{2+}$ & $\mathrm{Zn}^{2+}$ & $\mathrm{Fe}^{3+}$ & $\mathrm{Cu}^{2+}$ & $\mathrm{Zn}^{2+}$ \\
\hline None & $22 \cdot 4$ & $\mathbf{3} \cdot \mathbf{0}$ & $\mathbf{3} \cdot \mathbf{0}$ & 5 & 46 & 5 & 19 & 1100 & 161 & 297 \\
\hline $\begin{array}{l}\text { EDTA } \\
(1 \cdot 04 \mathrm{mM})\end{array}$ & $20 \cdot 8$ & $25 \cdot 0$ & $26 \cdot 0$ & 6 & 48 & 6 & 21 & 1084 & 139 & 320 \\
\hline None & $22 \cdot 5$ & $\mathbf{3} \cdot \mathbf{0}$ & $3 \cdot 0$ & 5 & 46 & 5 & 22 & 1100 & 161 & $\mathbf{3 5 0}$ \\
\hline $\begin{array}{l}\text { Ferrocyanide } \\
(84, \mu \mathrm{M})\end{array}$ & $20 \cdot 0$ & $59 \cdot 0$ & $51 \cdot 0$ & 4 & NA & 5 & 21 & NA & 171 & 280 \\
\hline
\end{tabular}

* When present, EDTA and ferrocyanide were added before or $24 \mathrm{hr}$ after inoculation respectively.

$\dagger$ In each case the initial concentration of trace metals in the medium plus inoculum of conidia was $\left(\mu\right.$ g./l.): $\mathrm{Fe}^{3+}, 2120 ; \mathrm{Cu}^{2+}, 242 ; \mathrm{Zn}^{2+}, 676$.

$\ddagger$ No analysis.

The effect on citric acid production of omitting single trace metals from the medium, both with and without ferrocyanide, was examined (Table 5). Omission of iron did not affect the mycelial dry wt. but it caused the iron content of the mycelium to be markedly decreased. In the absence of added iron, ferrocyanide only slightly stimulated citric acid production. Also in the absence of added iron, ferrocyanide did not modify the mould morphology to the small discrete pellet form; the growth remained as in the control. It may be concluded that the minimum iron supply for maximum citric acid production is greater than the minimum iron supply for mycelium production. Copper was taken up by the mycelium to a much smaller extent than iron or zinc. The copper present as contaminant in the medium (182 $\mu \mathrm{g}$./l.) was well above the maximum amount taken up by the mould, hence it is not surprising that omission of copper had no effect. Omission of zinc caused limitation of the mould growth by the zinc supply and greatly decreased the zinc content of the mycelium. Ferrocyanide did not stimulate citric acid production in zinc-starved mycelium. The morphology of the mycelium was in the form of large fimbriated pellets without zinc and ferrocyanide added. The presence of ferro- 


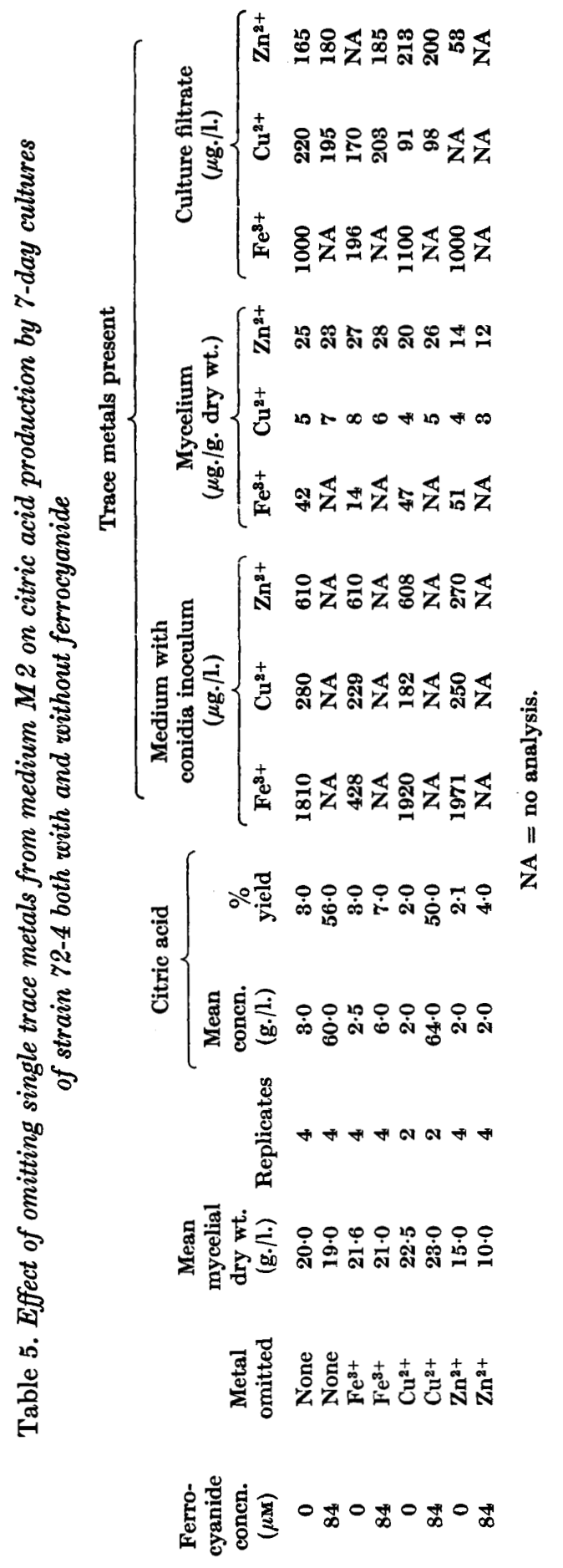


cyanide without added zinc produced the typical small discrete pellets usually obtained with added ferrocyanide. This result shows that growth in the small pellet form was not by itself a sufficient condition for maximum citric acid production.

\section{DISCUSSION}

The mechanism whereby Aspergillus niger produces citric acid in large amount under certain conditions is a problem of great interest. Citric acid is presumably a normal intermediate in the terminal respiratory metabolism of the mould and its massive excretion is apparently caused by a derangement of this metabolism. The conditions which favour the production of citric acid are: (1) special strains of the mould, (2) high oxygen supply, (3) a low pH value, about 2, (4) a special trace-metal balance. The latter condition is deduced largely by a consensus of opinion rather than from precise knowledge of the trace-metal balance. The stimulation of citric acid production by ferrocyanide may be interpreted as due to a favourable modification of the trace-metal balance. The stimulation by metal-chelating agents such as EDTA first reported by Choudhary \& Pirt (1965b) similarly seems to be due to modification of the trace-metal balance. The observation that the $\mathrm{Fe}^{3+}$ : EDTA ratio should be kept low and that ferrocyanide does not stimulate unless iron is present in excess of that required for growth suggests that there should be an unlimited supply of iron but supplied at a critical concentration which is controlled by ferrocyanide or chelating agent. The stimulations by ferrocyanide and chelating agents differ markedly in the effect of the time of addition. Chelating agents can stimulate when added to the culture at any time up to $72 \mathrm{hr}$ from time of inoculation or possibly later; on the other hand ferrocyanide stimulated only when added before $48 \mathrm{hr}$, that is, early in the growth period. This limitation of the ferrocyanide effect is evidence against the suggestion put forward by Martin (1955) that ferrocyanide has a direct action on the mould in stimulating citric acid production. The effect of the chelating agent at a later period, when most of the mycelium is formed, may be attributed to permeation of the lipid cell membrane by the undissociated acid and the binding of trace metals which have been taken up by the cell. It is assumed that ferrocyanide cannot do this. The lack of stimulation of citric acid production by the chelating agents NTA and DHEG may be attributed to the same properties which, as Choudhary \& Pirt (1965 $a$ ) suggested, prevent their having any action on mould morphology and on conidial germination.

Under the optimum conditions for citric acid production the mould always grew in the form of small discrete pellets like a suspension of sand particles. Perhaps this type of pellet formation should be included as the fifth special condition for citric acid production; it is, however, difficult to believe that this is anything other than a correlated effect caused by the same conditions which stimulate citric acid production.

The trace-metal analyses of mycelia indicate that the agents which stimulate citric acid production do not affect the total uptake of $\mathrm{Fe}^{3+}, \mathrm{Cu}^{2+}$ and $\mathrm{Zn}^{2+}$ by the mould. The analytical method for $\mathrm{Mn}^{2+}$ was not sensitive enough to detect this element in the medium or mycelium. It would be interesting to do so in view of the observation of Noguchi \& Johnson (1961) that $\mathrm{Mn}^{2+}$ may strongly inhibit citric acid production by Aspergillus niger; also the observation of Clark, Ito \& Tymchuk 
(1965) that ferrocyanide is particularly effective in removing $\mathrm{Fe}^{3+}$ and $\mathrm{Mn}^{2+}$ from the medium.

We also grew the mould in a stirred fermenter and in continuous-flow culture, but in these forms of culture citric acid was not produced in large amount and its production was not stimulated by ferrocyanide or chelating agents. In the stirred fermenter the mould grew in the viscous filamentous form. It thus appears that some other controlling factor remains to be discovered, or the agitation has to be of a type which permits formation of the right type of pellet morphology.

An equipment grant from the Science Research Council (D.S.I.R.) is gratefully acknowledged.

\section{REFERENCES}

Arman, P. (1957). M.Sc. Thesis, University of London; quoted by Abdulla, I. \& Smith, S. M. (1963). Influence of chelating agents on the concentration of some nutrients for plants growing in soil under acid and under alkaline conditions. J. Sci. Fd Agric. 14, 98.

Choudhary, A. Q. \& Pirt, S. J. (1965a). Metal-complexing agents as metal buffers in media for the growth of Aspergillus niger. J. gen. Microbiol. 41, 99.

Choudhary, A. Q. \& Pirt, S. J. (1965b). The role of metal-complexing agents in the production of citric acid by Aspergillus niger. J. gen. Microbiol. 41, iii.

Clark, D. S., Ito, K. \& Trmchuk, P. (1965). Effect of potassium ferrocyanide on the chemical composition of molasses used in the citric acid fermentation. Biotech. \& Bioeng. 7, 269.

Eden, A. \& Green, H. H. (1940). Micro-determination of copper in biological material. Biochem. J. 34 (ii), 1202.

Fujita, A. \& Iwatake, D. (1981). Determination of the true blood sugar without yeast. Biochem. Z. 242, 43.

Harris-Smith, R. H., Pirt, S. J. \& Firman, J. E. (1963). A ventilated germ-free cabinet for the microbiological laboratory. Biotech. \& Bioeng. $5,53$.

JACKSON, S. H. (1938). Determination of iron in biological materials. Ind. Engng Chem. analyt. Edn., 10, 302.

McCall, J. T., Davis, G. K. \& STEArns, T. W. (1958). Spectrophotometric determination of copper and zinc in animal tissue. Analyt. Chem. 30, 1345.

MARIER, J. R. \& Bounet, M. (1958). Direct determination of citric acid in milk with an improved pyridine-acetic anhydride method. J. Dairy Sci. 41, 1683.

MarTin, S. M. (1955). Effect of ferrocyanide on growth and acid production of Aspergillus niger. Can. J. Microbiol. 1, 644.

NoGuch, Y. \& Johnson, M. J. (1961). Citric acid fermentation of sugars purified with chelating resins. J. Bact. 82, 538.

Perlman, D. \& Sir, C. J. (1960). Fungal synthesis of citric, fumaric and itaconic acids. Prog. ind. Microbiol. 2, 167.

Pirt, S. J. \& Callow, D. S. (1958). Exocellular product formation by micro-organisms in continuous culture. I. Production of 2:3-butanediol by Aerobacter aerogenes in a single stage process. J. appl. Bact. $21,188$.

SANDELL, E. B. (1944). Colorimetric Determination of Traces of Metals. New York: Interscience Publishers. 